\title{
Adam Sitarek
}

Uniwersytet Łódzki, Centrum Badań Żydowskich

https://orcid.org/0000-0002-3958-7262

adam.sitarek@uni.lodz.pl

\section{Dziennik Viktora Hahna z łódzkiego getta ${ }^{1}$}

\begin{abstract}
Streszczenie
Dziennik pisany przez Viktora Hahna w łódzkim getcie to jeden z nielicznych dokumentów dotyczących getta łódzkiego znajdujących się w zbiorach Muzeum Żydowskiego w Pradze i jedyny znany dotąd dziennik spisany w języku czeskim. Prezentowane świadectwo, niewielkiej objętości, przedstawia zaledwie dwa miesiące pobytu w getcie łódzkim i obozie pracy przymusowej w Poznaniu, niemniej jest pod wieloma względami interesującym źródłem. Z jednej strony przybliża wojenne losy autora, z drugiej jest doskonałym obrazem społeczności praskich Żydów deportowanych do getta łódzkiego jesienią 1941 r., żyjących w zbiorowych miejscach zamieszkania, tzw. kolektywach. Ostatnie wpisy autora są wyjątkowym świadectwem człowieka, którego nazwisko znalazło się na listach deportacyjnych, a który niemal cudem ocalał dzięki dobrowolnemu zgłoszeniu się na roboty przymusowe.
\end{abstract}

\section{Słowa kluczowe}

getto łódzkie, Żydzi czescy, dzienniki Zagłady, egodokumenty

\begin{abstract}
Viktor Hahn's Łódź ghetto diary is one of the few documents concerning the Warsaw ghetto that can be found in the Prague Jewish Museum, and is the only diary written in Czech. The testimony, rather small in volume, discusses two months of the author's stay in the Łódź ghetto and a forced labor camp outside Poznań, but it nevertheless is an interesting source. On the one hand it presents the author's war-time experiences, and on the other, is an excellent picture of the Prague Jewish community deported to the Łódź ghetto in the autumn of 1941, who lived in collective residences, the so-called "collectives". The last entries are an exceptional testimony of a man whose name was included in the deportation lists and who by near miracle survived thanks to reporting for forced labor.
\end{abstract}

\section{Key words}

Łódź ghetto, Czech Jews, Holocaust diaries, ego-documents

${ }^{1}$ Bardzo dziękuję córce Viktora Hahna Sylvii Pustinie za uzupełnienia dotyczące biografii ojca i podzielenie się swoją historią, Zuzannie Hillard za nieocenioną pomoc w kontakcie z rodziną Viktora Hahna, Elżbiecie Czajce za pomoc w pozyskaniu dziennika, Wernerowi Imhofowi oraz ocalałemu z getta Josefovi Salomonovicowi za pomoc w wykonaniu transkrypcji, Sławomirowi M. Nowinowskiemu za tłumaczenie i cenne uwagi oraz Jiříemu Friedlowi z Historický ústav Akademie věd České republiky za konsultacje merytoryczne. Tłumaczenie i opracowanie dziennika stanowi część projektu „Leksykon getta łódzkiego" realizowanego w ramach Narodowego Programu Rozwoju Humanistyki. 


\section{Materiały}

W zbiorach Muzeum Żydowskiego w Pradze w zespole Dokumenty Prześladowań (Dokumenty perzekuce) znajduje się kilkudziesięciostronicowy rękopis sporządzony w języku czeskim, opisany jako Dziennik z Łodzi (Hahn Viktor, Deník z Lodže, załącznik nr 79). Jest to jeden z nielicznych dokumentów dotyczących getta łódzkiego przechowywanych w zbiorach praskiego muzeum ${ }^{2}$. Prezentowane tu świadectwo mimo niewielkiej objętości jest pod wieloma względami interesującym źródłem przybliżającym losy nie tylko jego autora, ale całej społeczności praskich oraz zachodnioeuropejskich Żydów deportowanych do getta łódzkiego jesienią $1941 \mathrm{r}$.

W grupie niemal 20 tys. uwięzionych w getcie Żydów pochodzących z Rzeszy i Protektoratu znalazło się wielu ludzi pióra kontynuujących działalność w nowej rzeczywistości oraz osób, które sięgnęły po pióro w obliczu doświadczeń prześladowania i przesiedlenia; do tych ostatnich najprawdopodobniej zalicza się autor omawianego źródła. Wśród najważniejszych dotąd opublikowanych świadectw autorstwa „Żydów zachodnich” znajdują się m.in. zapiski Oskara Rosenfelda ${ }^{3}$, reportaże Oskara Singera ${ }^{4}$ i Bernarda Heiliga ${ }^{5}$, teksty Alice de Buton ${ }^{6}$ i Petera Wertheimera ${ }^{7}$. Wszystkie wymienione osoby wiążemy z kręgiem Wydziału Archiwum administracji żydowskiej getta - jako jego pracownicy bądź współpracownicy zatrudnieni byli przy pracach nad „Biuletynem Kroniki Codziennej”, znanym szerzej jako Kronika getta łódzkiego ${ }^{8}$, oraz nad Encyklopediq getta ${ }^{9}$. Wkład tej grupy w ten drugi projekt jest szczególnie wyraźny - Oskar Singer był jednym z głównych wykonawców, Oskar Rosenfeld widnieje zaś jako autor wstępu - deklaracji programowej Encyklopedii ${ }^{10}$. W ostatnim czasie opu-

\footnotetext{
${ }^{2}$ Spośród 31 rekordów oznaczonych jako związane z Łodzią w tym zespole zdecydowana większość to karty pocztowe wysyłane z getta lub potwierdzenia nadania przekazów pieniężnych do getta.

${ }^{3}$ Fragmentami zapisy zostały sporządzone w formie dziennika, w dużej części jednak są to reportaże, eseje i szkice. Zob. Oskar Rosenfeld, Wozu noch Welt? Aufzeichnungen aus dem Getto Lodz, Frankfurt am Main: Neue Kritik, 2014. Obszerne fragmenty opublikowano w języku polskim w tomie Oblicza getta. Antologia twórczości z getta łódzkiego, red. Krystyna Radziszewska, Ewa Wiatr, Łódź: Wydawnictwo UŁ, 2017, s. 3-35.

4 „Przemierzając szybkim krokiem getto...” Reportaże i eseje z getta łódzkiego, tłum. Krystyna Radziszewska, Łódź: Oficyna Bibliofilów i Archiwum Państwowe w Łodzi, 2002. Trzy reportaże opublikowano także w: Oblicza getta..., s. 125-146.

${ }^{5}$ Bernard Heilig, Pierwsze siedem miesięcy w getcie Litzmannstadt. Przelotne wrażenia i obrazy [w:] Oblicza getta..., s. 103-124.

${ }^{6}$ Oblicza getta..., s. 147-160.

${ }^{7}$ Mowa tu o 10 hasłach do Encyklopedii getta, zob. Encyklopedia getta. Niedokończony projekt archiwistów z getta łódzkiego, wyd. Krystyna Radziszewska i in., Łódź: Wydawnictwo UŁ, 2014, s. 298.

${ }^{8}$ Kronika getta łódzkiego / Litzmannstadt Getto 1941-1944, t. 1-5, red. Julian Baranowski i in., Łódź: Wydawnictwo UŁ i Archiwum Państwowe w Łodzi, 2009.

${ }^{9}$ Encyklopedia getta...

${ }^{10}$ Oskar Rosenfeld, Encyklopedia getta [w:] ibidem, s. 3-4.
} 
blikowany został dziennik Irene Hauser ${ }^{11}$ - deportowanej z Wiednia gospodyni domowej, której zapiski, intymne i pokazujące bezradność, poza zeszytami Rosenfelda były dotąd jedynym znanym świadectwem autorstwa osoby deportowanej z Rzeszy sporządzonym w formie dziennika. Odkrycie prezentowanego dalej tekstu pozwala mieć nadzieję, że w magazynach archiwów, muzeów lub prywatnych kolekcji następne podobne teksty czekają na odnalezienie i upowszechnienie. Wskazówki pozwalające sądzić, że takie teksty powstawały, można odnaleźć m.in. w dzienniku Dawida Sierakowiaka, który w lipcu 1942 r. zanotował:

Byłem dziś po południu u Deutschowej. Poznałem tam niejakiego dra Freda Goldschmidta, spuchniętego już, byłego prokuratora z Breslau. Żona jego czytała urywki z jego książki o getcie (niezwykle już pono grubej), o ogromnej wartości literackiej. Pisze tylko po niemiecku, a książka składa się z rozlicznych szkiców, wierszy, opowiadań, obrazków itd. Jest on niezwykle płodny (do czasu wojny prawie że nie pisał) i mimo okropnych warunków pisze bez przerwy ${ }^{12}$.

Jesienne przesiedlenia Żydów z Rzeszy i Protektoratu były jednym z najważniejszych momentów w historii łódzkiej „dzielnicy zamkniętej” ${ }^{13}$. W grupie niemal 20 tys. „nowo wsiedlonych” - jak nazywano ich w getcie - najliczniejsza była reprezentacja prażan, licząca 4999 osób, przybyła do getta w pięciu transportach od 19 października do 3 listopada $1941 \mathrm{r}^{14}$ Mimo wspólnego tragicznego losu zauważalna była różnica między grupą przybyłą z Protektoratu a przedstawicielami miast z Rzeszy. Najbardziej widoczną stanowił język, ale szybko okazało się, że czescy Żydzi wyróżniają się przede wszystkim stopniem integracji z miejscową społecznością. Przełożony Starszeństwa Żydów Mordechaj Chaim Rumkowski w jednym z wystąpień do społeczności getta podkreślał, że „prażanie wykazują szczerą chęć pracy z pożytkiem dla społeczeństwa”, podkreślając jednocześnie, że „nie da się tego powiedzieć o większości przybyłej

${ }^{11}$ Irene Hauser, Dziennik z getta łódzkiego / Das Tagebuch aus dem Lodzer Getto, red. Ewa Wiatr, Krystyna Radziszewska, Łódź: Wydawnictwo UŁ, 2019.

${ }^{12}$ Dawid Sierakowiak, Dziennik, oprac. Ewa Wiatr, Adam Sitarek, Warszawa: ŻIH, 2016, s. 292.

${ }^{13}$ Więcej o deportacjach z jesieni 1941 r. zob. Adam Sitarek, „W obliczu trudnej konieczności". Administracja żydowska getta łódzkiego wobec wsiedleń Żydów z Rzeszy i Protektoratu (październik-listopad 1941 r.), „Zagłada Żydów. Studia i Materiały” 2012, nr 8, s. 331-347; Andrea Löw, Getto łódzkie / Litzmannstadt Getto. Warunki życia i sposoby przetrwania, tłum. Małgorzata Półrola, Łukasz Marek Plęs, Łódź: Wydawnictwo UŁ, 2012, s. 177-207.

${ }^{14}$ Do tej pory dzieje przesiedleńców z Pragi nie doczekały się szerszego opracowania w języku polskim. Jedyną próbą szerszego ujęcia problemu opartą na zestawieniu dokumentów i relacji jest praca Ghetto Litzmannstadt 1941-1944. Dokumenty a výpovědi o životě czeských židů v lodžském ghettu, oprac. Richard Seeman, Praha: Ústav mezinárodních vztahů ve spolupráci s Terezínským památníkem, 2000. 
ludności z innych miast”15. W Kronice getta zwracano uwagę na podejście czeskich Żydów do pracy w getcie, pisząc, iż wykazali oni w tym temacie „najwięcej zrozumienia"16, czego potwierdzeniem może być powołanie nowego oddziału Straży Ogniowej w grudniu 1941 r., złożonego przeważnie z prażan ${ }^{17}$, lub zaangażowanie wspomnianych wcześniej dziennikarzy i pisarzy Oskara Singera i Oskara Rosenfelda do pracy w Wydziale Archiwum. Transporty - jak nazywano grupy przybyłych z Zachodu - rozlokowano przede wszystkim w tzw. kolektywach, będących zbiorowymi miejscami zamieszkania urządzonymi w gmachach zamkniętych jesienią 1941 r. szkół. Do największych kolektywów praskich należały gmach przy ul. Franciszkańskiej 29, gdzie umieszczono kolektyw Praga IV, oraz gmach przy ul. Jakuba 10, gdzie oprócz prażan z transportu Praga V znaleźli się także Żydzi z Frankfurtu i Wiednia. W tym kolektywie mieszkał autor prezentowanego świadectwa ${ }^{18}$.

Niekorzystna struktura wieku w połączeniu z trudnościami adaptacyjnymi przesiedleńców z Rzeszy i Protektoratu sprawiła, że odnotowano bardzo wysoką śmiertelność w tej grupie mieszkańców getta, sięgającą w okresie do maja 1942 r. niemal 16 procent. Prażanie, zauważalnie młodsi od przybyłych z Rzeszy, umierali rzadziej - w analogicznym okresie śmiertelność w tej grupie wynosiła niewiele ponad 9 procent $^{19}$. Duża grupa spośród wsiedlonych do getta jesienią 1941 r. została deportowana do Chełmna w maju 1942 r.; do tej pory Żydzi zachodni cieszyli się względnym „bezpieczeństwem” i nie trafiali na listy deportacyjne ${ }^{20}$. Wysiedlenie zapowiedziano w obwieszczeniu $\mathrm{nr} 380$ wydanym 29 kwietnia $^{21}$, co Hahn lakonicznie odnotował w swoim dzienniku. Do 15 maja 1942 r. wywieziono do Chełmna i zamordowano niespełna 11 tys. Żydów z Rze-

${ }^{15}$ Kronika getta..., t. 1, zapis z listopada 1941 r., s. 345.

${ }^{16}$ Ibidem, s. 326.

${ }^{17}$ Kronika getta..., t. 1, zapis z 17 XII 1941 r., s. 384.

${ }^{18}$ Wiosną 1942 r. w związku z deportacją mieszkańców getta, w tym Żydów z Rzeszy i Protektoratu, do obozu zagłady w Chełmnie nad Nerem kolektywy stopniowo zamykano. Przy ul. Jakuba 10 po likwidacji kolektywu zorganizowano Resort Krawiecki nr 84 (Kronika getta..., t. 2, zapis z 16 IV 1942 r., s. 99).

${ }^{19}$ Obliczenia własne na podstawie tabeli 3 w: Löw, Getto łódzkie..., s. 199. Wobec podanych wyżej liczb interesującym wątkiem do zbadania wydaje się odnotowanie w Kronice getta większej liczby przypadków samobójstw wśród deportowanych z Protektoratu niż w grupie wsiedlonej do getta z Rzeszy.

${ }^{20}$ Dyskusja na temat losu Żydów z Rzeszy toczyła się w lokalnych władzach od marca 1942 r., w kwietniu tego roku do Kraju Warty przyjechali Heinrich Himmler i Wilhelm Koppe. Niebawem na rozkaz Himmlera zarządzono eksterminację niezdolnych do pracy Żydów zachodnich (Michael Alberti, Die Verfolgung und Vernichtung der Juden im Reichsgau Wartheland 1939-1945, Wiesbaden: Harrassovitz Verlag, 2006, s. 442-445).

${ }^{21}$ Obwieszczenie ukazało się w dwóch wersjach: pierwsza zawierała grupy wyłączone z wysiedlenia - posiadaczy Żelaznego Krzyża lub Odznaki za Rany i zatrudnionych, druga bez wymienionych grup zwolnionych z wysiedlenia. Zob. Rok za drutem kolczastym, oprac. Adam Sitarek, Ewa Wiatr, Warszawa: ŻIH, 2019, s. 503-505. 
szy i Protektoratu22. Wśród pozostałych w getcie „nowo przybyłych” największą grupą stanowili przybyli z Pragi - ponad 2,4 tys. osób ${ }^{23}$ (49 procent spośród wszystkich deportowanych z Pragi!). Tak wysoka liczba pozostałych czeskich Żydów była spowodowana dużą liczbą zatrudnionych spośród tej grupy. Kolejne deportacje do Chełmna, przede wszystkim tzw. wielka szpera z września 1942 r., oraz wysyłki do obozów pracy, w połączeniu z coraz tragiczniejszą sytuacją w getcie dziesiątkowały tę grupę. Do końca wojny przeżyło zaledwie 277 osób ${ }^{24}$, wśród nich autor prezentowanego dalej tekstu.

\section{Autor i jego tekst}

Viktor Hahn urodził się 21 sierpnia 1899 r. w Kosmonosach, miasteczku w kraju środkowoczeskim, położonym nieopodal miasta Mlada Boleslav. Hahnowie byli jedyną żydowską rodziną w mieście. Ojciec Viktora był rzeźnikiem, starszy brat jeszcze przed wybuchem wojny miał wyjechać do Szanghaju. Autor dziennika po ukończeniu studiów w szkole handlowej wyjechał do Pragi, gdzie pracował jako prokurent. W zapiskach wielokrotnie pojawia się imię Aša - narzeczonej Viktora. Para poznała się w Pradze. Aša, a właściwie Ana Moravskova pochodziła z katolickiej rodziny z Wiednia o czeskich korzeniach. Jej ojciec zakładał filię banku wiedeńskiego w Pradze, z tego względu rodzina przeprowadziła się do stolicy Czechosłowacji. Para przed wojną nie sformalizowała związku, dlatego Viktor został deportowany jako kawaler ${ }^{25}$. Mimo to starał się utrzymać kontakt korespondencyjny z narzeczoną, co dawało autorowi zapisków motywację do przetrwania. Jako ostatni adres przed deportacją widnieje ul. Jakubska 8 w Pradze ${ }^{26}$, a w rubryce „wykonywany zawód” wpisano „urzędnik bankowy" - Bankbeamter. Do getta trafił wraz z piątym transportem z Pragi (transport nr 20) 3 listopada 1941 r. Razem z całą grupą 999 osób został ulokowany w kolektywie przy ul. Jakuba 10, skąd z końcem kwietnia miał trafić do mieszkania w getcie, gdyż w budynku kolektywu planowano uruchomienie Resortu Krawieckiego. Hahn od 1 kwietnia 1942 r. zatrudniony był w Pralni Chemicznej (Chemische Reiningungs- und Waschenanstalt) ${ }^{27}$ mieszczącej się przy ul. Drewnowskiej 77. Wykonywał tam różne prace, o czym świadczą zapisy w dzienniku: „obijanie się przy pompie” (17 kwietnia), „praca w montowni” (19 kwietnia) „noszenie czystego prania na dół” (20 kwietnia). Inne zapisy („zarobiłem 40 ma-

\footnotetext{
${ }^{22}$ Adam Sitarek, „Otoczone drutem państwo”. Struktura i funkcjonowanie administracji żydowskiej getta łódzkiego, Łódź: IPN, 2015, s. 224-225.

${ }^{23}$ Löw, Getto łódzkie..., tabela 5, s. 224.

${ }^{24}$ Ghetto Litzmannstadt..., s. 19.

${ }^{25}$ Informacje od córki Viktora Hahna.

${ }^{26}$ ITS Digital Archive, Arolsen Archives (dalej ITS AA), 5039713, Ustredni Kartoteka Transporty.

${ }^{27}$ Archiwum Państwowe w Łodzi (dalej AP Łódź), Akta Przełożonego Starszeństwa Żydów (dalej PSŻ), 1290, Zaświadczenie o zatrudnieniu, k. 1322.
} 
rek ze sprzedaży" - 2 kwietnia) wskazują, że mogła to być jego pierwsza praca w getcie i do tej pory utrzymywał się z wyprzedawania przywiezionych ze sobą rzeczy, co było powszechnym zjawiskiem wśród wsiedleńców z Rzeszy i Protektoratu. Wraz z ogłoszeniem deportacji Żydów z Rzeszy i Protektoratu ${ }^{28}$ autor 2 maja został skierowany do wysyłki (nazwał to „nakazem wyprowadzki”). Po interwencji i skierowaniu prośby o zwolnienie z deportacji jako osoba pracująca w resorcie ${ }^{29}$ znalazł się on w grupie osób tzw. nadkontyngentu - zatrudnionych w getcie, lecz mimo to umieszczonych na listach deportacyjnych ${ }^{30} .14$ maja w przedostatni dzień deportacji - po wejściu Służby Porządkowej do kolektywu został on skierowany do wysyłki razem ze współlokatorami. Wcześniej udało mu się tego uniknąć, gdyż w kolektywie zdarzyły się wypadki chorób zakaźnych i panowała kwarantanna: „Gdyby nie nasza «złota» kwarantanna, było by nas dzisiaj o wiele mniej" - zanotował w dzienniku pod datą 13 maja. Tymczasem jednak zgłosił się do grupy osób kierowanych do pracy poza getto - odpowiadając na apel Urzędu Pracy ${ }^{31}$. Po stawieniu się przed komisją lekarską znalazł się w grupie 200 osób (w tym 130 ochotników), które miały być wysłane do Poznania, co uratowało go przed deportacją do Chełmna. 15 maja - w dniu wyjazdu ostatniego transportu Żydów zachodnich do Chełmna - Hahna umieszczono w Centralnym Więzieniu w getcie przy ul. Czarnieckiego, pełniącym funkcję punktu przejściowego, a następnie został razem z grupą robotników przewieziony do obozu przejściowego na terenie Litzmannstadt - prawdopodobnie na ul. Łąkowej ${ }^{32}$, stamtąd po badaniach niemieckiej komisji lekarskiej stawił się na dworcu Litzmannstadt Hauptbahnhof (obecnie Łódź Kaliska), skąd odjechał w kierunku Poznania. Daty zapisów z dziennika wskazują, że trafił on razem z grupą 120 osób do obozu pracy w Kobylympolu na wschód od Poznania ${ }^{33}$. Od 17 do 28 maja przebywał na terenie obozu pracy w Poznaniu i tam pracował przy budowie linii kolejowej oraz rozładunku wagonów z materiałami budowlanymi. Ostatni zapis jest opatrzony datą 28 maja $1942 \mathrm{r}$. Z zachowanych materiałów wiadomo, że 26 stycznia 1944 r. osadzono go w Sachsenhausen (numer więźnia 75193) ${ }^{34}$, a później, 13 kwietnia 1945 r., trafił do obozu Mauthausen,

${ }^{28}$ Zob. przypis 20.

${ }^{29}$ Pismo zachowało się w AP Łódź, PSŻ 1290, Podanie Viktora Hahna, k. 1324.

${ }^{30}$ Kronika getta..., t. 2, zapis z 13-14 V 1942 r., s. 177. Na podaniu Hahna sporządzonym 3 maja z prośbą o zwolnienie z deportacji znalazła się pieczęć „nadkontyngent“ (AP Łódź, PSŻ 1290, Podanie Viktora Hahna, k. 1324).

${ }^{31}$ Kronika getta..., t. 2, zapis z 13-14 V 1942 r., s. 178.

${ }^{32}$ Sugeruje to zapis w dzienniku mówiący o przejściu na dworzec kolejowy w czasie 1015 minut.

${ }^{33}$ W miejscowości Kobylepole na wschód od Poznania znajdował się obóz pracy dla Żydów, którego robotnicy zatrudnieni byli przez firmy Grun \& Bilfinger A.G. Mannheim oraz Heino Hecht (Anna Ziółkowska, Obozy pracy przymusowej dla Żydów w Wielkopolsce w latach okupacji hitlerowskiej (1941-1943), Poznań: Wydawnictwo Poznańskie, 2005, tabela 18, s. 95).

${ }^{34}$ ITS AA, 4380722, Karta więźnia. 


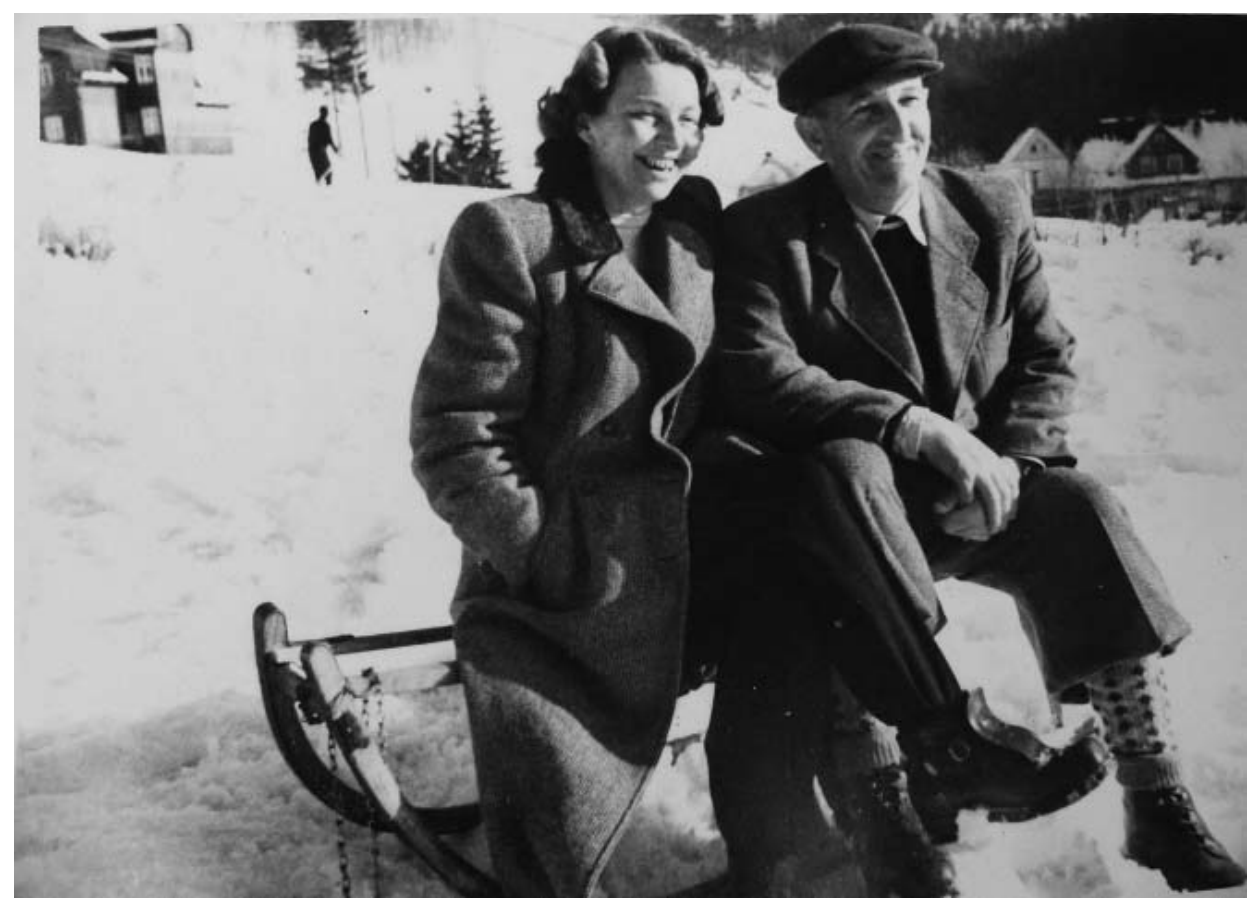

Viktor i Aša Hahnowie po wojnie (zbiory prywatne Sylvii Pustiny)

gdzie otrzymał numer $138430^{35}$ i widniał na listach więźniów podobozu Ebensee, gdzie został wyzwolony 5 maja $1945 \mathrm{r}^{36}$ Po wojnie wrócił do Pragi ${ }^{37}$, gdzie ożenił się z Asą i gdzie urodziła się ich córka Sylvia. W stolicy Czechosłowacji mieszkał aż do śmierci w listopadzie $1981 \mathrm{r}^{38}$ Niestety, brakuje informacji o okolicznościach, w jakich dziennik znalazł się w kolekcji praskiego muzeum.

${ }^{35}$ ITS AA, 1490553, Victor Hahn; ibidem, 1321817, Lista z 13 IV 1945 r.; ibidem, 1280988, Lista więźniów.

${ }^{36}$ United States Holocaust Memorial Museum (USHMM), RG-19.027, List of Czechoslovakian displaced persons in Ebensee, 18 V 1945 r., k. 14; ITS AA, 13043308, Lista czechosłowackich więźniów w obozie koncentracyjnym w Ebensee; ibidem, 103701032, Formularz Międzynarodowego Czerwonego Krzyża. W korespondencji zachowanej w archiwum w Bad Arolsen na jednej z kart podana jest informacja, że Hahn trafił latem 1943 r. do obozu Guttenbrunn, a wiosną 1944 r. do Auschwitz i został wyzwolony w maju 1945 r. w Austrii; informacje te nie znajdują potwierdzenia $w$ innych dokumentach znajdujących się $w$ tym samym archiwum (ITS AA, 103701017, Karta korespondencji).

${ }^{37}$ ITS AA, 78783596, Lista Żydów i ofiar rasowych prześladowań w Czechach i Morawach do 31 X $1945 \mathrm{r}$.

${ }^{38}$ Informacje od córki Viktora Hahna. 
Tekst spisywany przez Hahna niewątpliwie można uznać za klasyczny przykład gatunku dzienników, w których wyraźne są prywatna perspektywa obserwacyjna oraz brak dystansu czasowego do opisywanych wydarzeń ${ }^{39}$. Początkowo bardzo lakoniczne, komunikaty wraz z upływem czasu nabierają coraz bardziej rozbudowanego, refleksyjnego charakteru. Z surowego sprawozdania z codziennych czynności, informacji o wysokości zarobków i opisu posiłków stopniowo rozwijają się w szersze omówienia dotyczące sytuacji autora, a także, co wpływa na wartość świadectwa, relacji wewnątrz społeczności wsiedleńców z Protektoratu mieszkających w kolektywie - wzajemnej pomocy i konfliktów, organizacji czasu, rozrywek, przepływu informacji, relacji między wsiedleńcami a ludnością miejscową w getcie (liczne krytyczne uwagi autora co do zachowania miejscowych Żydów, np. „polski bałagan” - 4 maja, czy „Polacy to okropni ludzie, to są zwierzęta, nie wiem, jak dalej będzie układać się między nimi a nami!" - 17 maja). Tekst jest odarty z emocji, dramatyczne wydarzenia, jak choćby śmierć dwóch współlokatorów w jednym dniu (zapis z 22 kwietnia), są podane w suchym, niemal urzędowym stylu. Autor wyraźnie ożywia się jedynie, pisząc o wspomnianej Ašy - narzeczonej, która pozostała w Protektoracie.

Tekst był spisywany dzień po dniu od 1 kwietnia do 28 maja 1942 r., każda notka zawiera datę, wpis był sporządzany z reguły na koniec każdego dnia i stanowi niejako jego podsumowanie. Nie ma pewności, czy prezentowany tekst stanowi całość zapisów Hahna. Nie jest to wykluczone, choć w dzienniku nie odwołuje się on do wcześniejszych zapisów ani nie pisze nic o motywach. Potwierdzeniem tej tezy może być zapis z wewnętrznej strony okładki zeszytu, gdzie podał bardzo dokładną wagę z lutego i marca (1942 r.?).

\section{Nota edytorska}

Rękopis sporządzono ołówkiem kopiowym i zwykłym na połówce zeszytu formatu zbliżonego do A5 na 38 gładkich kartach w bardzo dobrym stopniu zachowania. Tekst jest czysty, pisany czytelnym charakterem, zawiera zaledwie dwa skreślenia wynikające z typowej omyłki, których zdecydowano się nie zaznaczać w niniejszej edycji. Jedno podkreślenie, w zapisie z 8 maja, pochodzi od autora i zdecydowano się je pozostawić. Tekst został sporządzony w języku czeskim - jest to jedyne znane do tej pory świadectwo z łódzkiego getta powstałe w tym języku. Każdy wpis był opatrzony numerem dnia, dla czytelności, w miejscach, gdzie tego nie uczynił autor, zdecydowano uzupełnić je dodanym w nawiasie kwadratowym cyfrowym oznaczeniem miesiąca. Sławomir M. Nowinowski starał się oddać w przekładzie charakter dokumentu i języka autora, co widać choćby w pozostawieniu użytych przez Hahna niemieckich nazw, np.

${ }^{39}$ Posiłkuję się tutaj typologią zaproponowaną przez Jacka Leociaka (idem, Tekst wobec Zagłady. (O relacjach z getta warszawskiego), Wrocław: Fundacja na Rzecz Nauki Polskiej, 1997, s. 20). 
Zusatz Karte czy Aelteste. Pozostawiono charakterystyczne czeskie nazwy, które nie mają odpowiednika w języku polskim (m.in. haše, radokaps). Poza aparatem pochodzącym od autora opracowania tekst zawiera także przypisy od tłumacza, zaznaczone (przyp. tłum.). W zapisie z 13 maja zaznaczono symbolem ${ }^{\mathrm{a}-\mathrm{a}}$ fragment, który spaginowano jako ostatnie dwie karty dokumentu, jednak ewidentnie pochodzi właśnie z tego dnia, a jego przesunięcie na koniec było spowodowane prawdopodobnie oddzieleniem kart z zeszytu. 


\section{Viktor Hahn}

\section{[Dziennik z Łodzi]}

Ważyłem:

23 II 72,70 kg

8 III 72,40 [kg]

24 III 71,50 [kg]

$10 \mathrm{~V} 64,20$ [kg]

Zahřebská ${ }^{40}$

[Kwiecień 1942 r.]

1 IV 0 wpół do ósmej byłem w Amcie dla Eingesiedelte ${ }^{41}$, stamtąd zostałem odprowadzony do pralni (resort) ${ }^{42}$. Do domu przebrać się i tego samego dnia pierwszy dzień pracy.

2 [IV] Zostałem w domu, żyd[owskie] święto, i zarobiłem 40 marek na sprzedaży.

3 [IV] W resorcie po południu czułem się źle, poszedłem się położyć.

4 [IV] sobota. Chory, zostałem w domu. Wielka Sobota ${ }^{43}$.

5 [IV] Wielkanoc. Resort.

6 [IV] Dzień czystości. Sprzątanie w domu. Poszedłem w deszczu do resortu na obiad. Potem zarobek 12 marek.

7 [IV] Nic nowego, resort. Kupiony drugi obiad za 6,5 marki. Wieczorem spacer z panią Novákovą.

8 [IV] 8 dni w resorcie. Negocjacje w sprawie przedłużenia. Klops za 2,5 marki.

9 [IV] W resorcie kupione 2 klopsy, wieczorem ziemniaki. Znalazłem wszy.

10 [IV] Nic nowego. 1 klops.

11 IV Sobota w resorcie.

${ }^{40}$ Jest to prawdopodobnie nazwa ulicy w Pradze, w dzielnicy Královské Vinohrady. Znajduje się jednak w dużej odległości od dzielnicy Nusle, w której mieszkał autor dziennika.

${ }^{41}$ Wydział dla Wsiedlonych - instytucja administracji żydowskiej getta odpowiedzialna za sprawy Żydów przesiedlonych do getta z Rzeszy i Protektoratu oraz gett prowincjonalnych Kraju Warty. Biura wydziału znajdowały się przy ul. Rybnej 8. Więcej na temat wydziału zob. tekst Krystyny Radziszewskiej w niniejszym numerze.

${ }^{42}$ Autor pracował w Pralni Chemicznej mieszczącej się przy ul. Drewnowskiej 77.

${ }^{43}$ Podanie świąt chrześcijańskich jako punktu odniesienia dla autora może wskazywać, że kultura ta odgrywała w jego życiu ważną rolę. Wiadomo, że jego narzeczona Asa była katoliczką. 
12 [IV] Niedziela. Znów wspominam, jak w każdą niedzielę. Awizowano mi 2 przekazy ${ }^{44}$. W resorcie zostały nam nadane numery ${ }^{45}$. Wieczorem biegunka.

13 [IV] 0 godz. 12 po zupie poszedłem do domu. Po południu za 9 marek zrobili mi placki z moich ziemniaków.

14 [IV] Wreszcie ładna pogoda. Resort. Potem zarobek 16,50 marek. Odebrałem 2 razy 10 marek i zostało mi wypłacone 5 marek. Wieczorem spacer.

15 [IV] Znów ohydnie. Potwierdziłem odbiór 2 razy 10 marek. Oczywiście od Lessów. Przed południem byłem sam na poczcie [i] fasowałem sałatki.

16 [IV] Resort. Rano zimno, potem ładnie. Chleb dopiero po południu.

17 [IV] Obijanie się przy pompie w resorcie - do godz. 2. Zarobek 10 marek. Złapałem gołębia ${ }^{46}$.

18 IV Sobota. Zostałem w domu, było pięknie. Zarobek 45 marek. Zakupiony za 20 marek chleb ( $\left.1 \frac{1}{2} \mathrm{~kg}\right)$, za 6,50 [marek] margaryna i za 5 marek zupa ziemniaczana z moich ziemniaków. Wieczorem wyprowadził się Heisler i zniknął chleb za 20 marek.

19 [IV] Wziąłem pierwszą wypłatę w resorcie, i to 22,10 marki. Ładna pogoda i praca w montowni. Zafasowałem pierwsze papierosy (18 sztuk). W getcie zostały wprowadzone opłaty dla niepracujących powyżej 10 lat ${ }^{47}$. Zupełnie zapomniałem, że to niedziela.

20 [IV] Usuwanie żelaza - noszenie czystego prania na dół. Zranienie w palec. Przed południem ugotowano 6 ziemniaków. Feldmannovie przeprowadzili się.

21 [IV] Po południu kąpiel, bardzo miło, jadłem z Mendelov[ými] ostatnie konserwy rybne i dokończyłem chleb. Ładna pogoda. Zarobek 6,50 marek.

22 IV Bez chleba do pracy. W gazetach dobre wieści, ale dzień tragiczny: rano umarł mój współlokator Heisler, wieczorem ogłoszono kwarantannę, a późno w nocy zmarł pan Hirsch, który spał [na pryczy] pode mną.

23 [IV] Pierwszy dzień kwarantanny ${ }^{48}$. Zjadłem dużo chleba i puding.

24 [IV] 0 godz. 10 wyjście do odwszalni. Kąpiel o pół do piątej, do tego czasu oczekiwanie względnie leżenie na siennikach. Kąpiel była świetna, potem odpoczynek i dobrze przespana noc.

${ }^{44}$ Deportowani z Rzeszy i Protektoratu w pewnych okresach otrzymywali od swoich rodzin i znajomych przekazy pieniężne do getta. Ekwiwalent wypłacano na poczcie w markach gettowych (tzw. kwitach markowych). Niejednokrotnie sumy te były ogromnym wsparciem dla więzionych w getcie Żydów zachodnich, pozwalały im bowiem zakupić artykuły pierwszej potrzeby.

${ }^{45}$ Karta pracy autora nosiła numer 782.

${ }^{46}$ Brak żywności zmuszał mieszkańców getta do łapania gołębi, a także przebywających na terenie getta zwierząt domowych, o czym wspominano w Kronice getta.

${ }^{47}$ Kronika getta nie porusza kwestii takich dodatkowych opłat.

${ }^{48} \mathrm{~W}$ kolektywach z powodu wybuchu ognisk chorób zakaźnych wprowadzano często kwarantannę połączoną z przymusowym kierowaniem jego mieszkańców do kąpieli, by zapobiec ich rozprzestrzenianiu się. 
25 [IV] Noc [szybko] minęła. Rano zakupione 2 [porcje] zupy, za 5 marek i 4 marki. Potem 2 [porcje] zupy w kolektywie, gdzie wróciliśmy w pół do drugiej. Ziemniaki, które przyniosła pani Nováková i podgrzała pani Seligmannová. Generalne sprzątanie i mycie po dezynfekcji. Wieczorem zwrot ku lepszemu. W końcu Bronner przyniósł mi kiełbasę z Zusatz-Karten ${ }^{49}$. Codziennie będzie zupa w resorcie.

26 [IV] Niedziela, znów wspominanie. Przed południem mięso na Z[usatz]-K[arte], po południu 2 [porcje] zupy i kiełbasa z resortu. Graliśmy w remika (w karty), a potem wygrzewaliśmy się w słońcu na podwórku.

27 [IV] Znów bez chleba. Zimno. Dostałem na Z[usatz]-K[arte] 4 kg ziemniaków i oddałem pożyczone. Potem wieczorem rybki i świetna sałatka. Ryby wnet przygotowane. [Gra w] karty.

28 [IV] Zimno. 0 godz. 8 rano zupa od pani Seligm[annovej], potem odgrzana zupa z 27 kwietnia i chleb z sałatką. Graliśmy w karty, czytałem radokaps ${ }^{50}$, a nastrój zupełnie zły. Wieczorem zupa ziemniaczana i chleb z kiełbasą. W kolekt[ywie] fasowano $7 \mathrm{dkg}$ mięsa, mielonego.

29 [IV] Rano dowiedzieliśmy się o przydzieleniu mieszkania dla nas. Przed południem mięso mielone. Dobry barszcz czerwony. Wieczorem rozlepiono plakaty o eksmisji nowych przesiedleńców i wiele dyskusji.

30 [IV] Zimno. Ratowanie się i sprzedawanie, co się tylko da. Wszyscy sprzedają ubrania, buty itd., a podwórko pełne Polaków ${ }^{51}$. Chleb do niedzieli, tj. na 3 dni.

Jestem 7 dni na kwarantannie. Robię pożyczony puding. Bardzo dokuczliwy, denerwujący dzień, a wieczorem zebranie dotyczące wyprowadzki. Wiele przemówień, dyskusji i oczekiwania nadchodzących wydarzeń.

[Maj $1942 \mathrm{r}$.]

1 [V] Pierwszy maja. Kiepska pogoda i taki sam nastrój. Rano zupa ziemniaczana. Pani Fleicherowa prała mi 2 koszule i nosiłem wodę. $1 \mathrm{dkg}$ margaryny kosztuje 4 marki.

2 [V] Pada deszcz. Fasowało się $4 \frac{1}{2} 2 \mathrm{dkg}$ margaryny, rano zupa ziem[niaczana]. Po południu fasowane buraki czerwone. Zły nastrój. Wieczorem dostałem nakaz wyprowadzki, od razu napisałem i złożyłem podanie, abym mógł zostać. Wieczorem zebranie i rozdanie arkuszy ankiet.

3 [V] Znowu niedziela na kwarantannie. Wreszcie przyjemnie. Rano byłem w drogerii po spirytus, a na śniadanie zjadłem znów zupę ziemniaczaną. Dom

${ }^{49}$ Zusatz-Karte (niem. karta na dodatek) - kupon, na który przysługiwał dodatkowy przydział żywności w formie zupy bądź suchego prowiantu. Słowo Zusatz przeszło do humoru getta - tłumaczono je jako „przyjaciółka (kochanka) dygnitarza, jego prawdziwy atrybut” (Encyklopedia getta..., s. 244).

${ }^{50}$ Radokaps (cz., skrót wyrażenia roman do kapsy) - powieść do kieszeni, potoczne określenie tanich edycji popularnej beletrystyki (przyp. tłum.).

${ }^{51}$ Tzn. polskich Żydów. 
ponownie pełny kupujących. Po południu dr Bayer oznajmił, że kwarantanna zostaje przedłużona, na razie więc nigdzie nie jedziemy.

4 V Pada deszcz. Dokładnie dzisiaj mija 6 miesięcy naszego pobytu w getcie. Moja prośba została pozytywnie rozpatrzona, a więc zostaję. Wysłałem [w ślad] za wysiedlonymi 5 kart [pocztowych]: dwie do Ašy, [po jednej do] matki, Emila i Lessów. Odjechali w deszczu. Byłem w resorcie po obiad. Wieczorem czyściliśmy obierki ziemniaczane, a pani Fleischerová zrobiła z nich zupę haš $e^{52}$. Dr Gotschalk, przez którego mamy kwarantannę, wrócił ze szpitala, jest prawie zdrowy i może wychodzić na zewnątrz. Ale my wciąż mamy kwarantannę: polski bałagan. Wieczorem znowu było zebranie. Sporządzaliśmy nowe spisy, tych, którzy zostali.

5 [V] Rano myliśmy i czyścili obierki ziemniaczane na haše. Zimno i pada śnieg. 1 dkg czosnku kosztuje 4 marki, margaryna 6 marek, 5 dkg kiełbasy sprzedaje się za 10 marek, chleb kosztuje przeszło 250 marek, tak więc ceny katastrofalne, niemożliwe. Kolektywna zupa na obiad dobra i [do tego] dwa razy. Wypożyczyłem sobie: Když nastaly deště ${ }^{53}$ i trochę czytam. Ta cała kwarantanna jest psu na buty. Każdy chodzi, gdzie chce, i robi, co chce, mimo że drzwi we dnie i w nocy pilnuje 2, 3 strażników, czyli izolatorów. Pomieszczenia są pełne porzuconych przedmiotów, wzięliśmy palnik spirytusowy, spirytus dostaniemy w drogerii, 10 dkg za 3 marki.

Pod wieczór zmęłliśmy czyste obierki i pani Fleischerová ponownie nam z nich zrobiła zupę haše na kolację. Znalazłem po wysiedlonych 2 ładne garnki do gotowania i słoik po marmoladzie. Szczyt komedii: dr Gotschalk, który zachorował na tyfus, zgłosił się ochotniczo do wyjazdu i przed południem wyruszył do punktu zbornego - a my wciąż na kwarantannie. $W$ rozporządzeniach dotyczących wyjazdów Aelteste $e^{54}$ ogłaszał, że można ze sobą zabrać 12,5 kg bagaży. Przedwczoraj odjechał pierwszy transport, wczoraj drugi i w obu zabrano [ludziom] wszystko, tj. plecaki, chlebaki i to, co mieli w rękach. Mężczyźni wyjechali więc tylko z tym, co mieli na sobie względnie w kieszeniach, z niczym więcej.

Wszystko jest tu polskie: Przed kilkoma dniami policja weszła na nasze podwórko i wygnała oraz pobiła Polaków, którzy tam od nas kupowali. Kiedy już ci ludzie znaleźli się na zewnątrz, [policjanci] zamknęli drzwi i sami wykupili wszystko, co mieliśmy i chcieliśmy sprzedać. Poza tym mamy od 1 maja polską kuchnię, gotuje lepiej niż nasze, a w zupie jest o wiele więcej ziemniaków. Rano dostajemy kawę, wieczorem nic.

${ }^{52}$ Haše - specjalność kuchni czeskiej, zupa z mielonym mięsem, w gettowych warunkach zastępowanym np. mielonymi obierkami ziemniaków (przyp. tłum.).

${ }^{53}$ Když nastaly deště - prawdopodobnie chodzi o powieść Louisa Bromfielda The Rains Came, której pierwsze czeskie wydanie w tłumaczeniu Anny Kučerovej ukazało się w Pradze w 1939 r. (przyp. tłum.).

${ }^{54}$ Przełożony Starszeństwa Żydów - Mordechaj Chaim Rumkowski. 
W nocy byłem 2 razy na dworze, dostałem lekkiej biegunki, pewnie po tej zupie z obierków. Ustępy są stale bardzo zanieczyszczone i wieczorem na zebraniu przegłosowano opłatę 1 marki na osobę za doprowadzenie do porządku ustępu, schodów i korytarzy.

6 V Dzisiaj o godz. 7 odjechał nasz transport. Według pisma [skierowanego] do nich także musieli tu wszystko zostawić. W punkcie zbornym dostali rano kawę, w południe i wieczorem dobrą zupę z mięsem i $28 \mathrm{dkg}$ chleba na dzień. $\mathrm{Na}$ drogę każdy otrzyma 1 bochenek, to znaczy $2 \mathrm{~kg}$ chleba. Pada deszcz, mają złą drogę. Rano znów byłem na dole, chociaż biegunka ustaje. Przed południem ponownie sortowaliśmy obierki na wieczorną zupę. Na przekąskę odgrzałem sobie na maszynce spirytusowej wczorajszą resortową zupę, była bardzo smaczna.

W niedzielę nie było w resortach papierosów. Wczoraj ponownie rejestrowano Zusatz-Karten i papierosy znów będą. Ja wprawdzie nie palę, ale ciągle muszę oddawać 3 papierosy co 2 dni panu Bronnerovi, z którym pracuję w resorcie, za to, że codziennie przynosi mi zupę i kiełbasę. Kiełbasę wczoraj sprzedałem pani Hellerovéj dla jej chorego męża za 6 marek, na zewnątrz kosztuje ona 10-11 marek.

Pod wieczór ugotowałem sobie trochę kakao z wodą i przegotowaną herbatę dla uniknięcia biegunki. $10 \mathrm{dkg}$ spirytusu za 4,50 [marki]. Wydali nam á konto $20 \mathrm{dkg}$ chleba, jutro otrzymamy pozostałe $14 \mathrm{dkg}$ i $1 \mathrm{~kg}$ na osobę. Dlatego miałem na kolację chleb i 5 dkg kiełbasy. Obierki będą jutro. Właśnie wyszedł od chorego Hellera dr Natanson, powiedział nam, że są dobre wieści, a za 3 tygodnie koniec. Daj Boże. Lewiatinowie, którzy zawsze byli dla mnie mili i dali mi sporo jedzenia, zdziwili się, że tak źle wyglądam.

Brakuje mi tłuszczu, tak jak wszystkim pozostałym. Ale mniejsza o to, z pewnością wytrzymam i wszystko przeżyję, z powodu Ašy.

7 V Nagle nastała ładna pogoda. Przed południem ugotowałem sobie zupę z kluskami, mam jeszcze trochę mąki. Potem rozdano resztę chleba - $14 \mathrm{dkg}$ na osobę i $1 \mathrm{~kg}$ na kolejne 4 dni, tzn. do poniedziałku. Czuję się jakoś słabo, ziemniaczane obierki prawdopodobnie nie wyszły mi na zdrowie. Pan Fleischer jednak czyści obierki ponownie, uprzednio płukaliśmy je pod pompą. Od zimnej wody zgrabiały mi ręce. Chleb kosztuje 400 marek, tzn. 50 marek za ćwierć kilo, naszych 500 koron $^{55}$, opłakane warunki. 10 dkg ogórka kosztuje 14 marek. Po południu podgrzałem sobie kawę z rana, zagotowałem jeszcze raz na maszynce spirytusowej i dodałem trochę mieszanki kawowej. Robię to zresztą teraz w każde popołudnie, a potem odgrzewam sobie resortową zupę. Bronner z resortu powiedział mi dziś, że kilku Niemców ${ }^{56}$, z którymi przyszedłem do resortu, już wyjechało. Graliśmy w bulkę ${ }^{57}$ i czytałem książkę ([Když nastaly] deště). Po południu poszedłem z panią Novákową do Feldmanów i kupiłem zarazem $15 \mathrm{dkg}$

\footnotetext{
${ }^{55}$ Tzn. pieniędzy obiegowych na terenie Protektoratu Czech i Moraw (przyp. tłum.).

${ }^{56}$ Tzn. niemieckich Żydów, deportowanych do getta jesienią $1941 \mathrm{r}$.

${ }^{57}$ Bulka (cz.) - czeska gra karciana (przyp. tłum.).
} 
twarogu á 2 marki. Sprzedałem natomiast $5 \mathrm{dkg}$ resortowej kiełbasy za 8 marek. Panuje zły nastrój, zwłaszcza wieczorem. Zatrzymałem się u Sašy. Był tam dr Natanson. Oczekuje rozstrzygnięcia w ciągu 3 tygodni, a w sierpniu chce być $\mathrm{w}$ domu. Twaróg z chlebem smakował wspaniale, ale niestety świeżego chleba brakuje. Mówi się, że do Litzmannstadt ma przybyć kolejne 20000 ludzi z tutejszej okolicy, mam nadzieję, że to nieprawda. Resorty, które nie pracują na potrzeby wojska, podobno mają być zlikwidowane. Mnie by to jednak nie dotyczyło, ponieważ my pierzemy względnie czyścimy wyłącznie odzież wojskową.

$8 \mathrm{~V}$ Rano w łóżku chleb z twarogiem (wczoraj wieczorem odstąpiłem pani Hechtovéj 5 dkg twarogu za 5 marek). 0 godz. 10 wczorajsza resortowa zupa. Przed południem wyczyściłem garnitur i wywietrzyłem śpiwór, a następnie ogoliłem się. Oglądałem mieszkanie, które nam przydzielili, to olbrzymi zimny pokój, źle oświetlony, ma tylko jedno okno w rogu, a zatem nie dla nas. Wczoraj ponoć znów odebrali [wywożonym] wszystko na torach. W południe dostałem od pani Hellerovéj jeszcze jedną [porcję] barszczu czerwonego. W zamian odstąpiłem jej za 6 marek aspirynę, dla chorego męża. Poza tym nastała ładna pogoda, słońce, wszyscy mówią, że to dobrze, a po mieście krąży pełno najprzeróżniejszych fantastycznych doniesień. Po południu wytrzepałem i wyczyściłem swoje palto i ogoliłem się. Graliśmy znów w karty, aby zabić czas. Poważny nastrój, jak w piątek. Potem jeszcze zajrzałem do Sašy i do Guttmannów. Znów się dziwili, że tak źle wyglądam. Mają rację, widziałem siebie w dużym lustrze. To nie moja wina, jem wystarczająco. Ludzie nie wiedzą, co mają robić, Otto Seligman ponownie mnie teraz zapytał, czy mają się ochotniczo zgłosić na wyjazd stąd. Guttmannowie powiedzieli mi, że ma tu przyjść z okolic miasta 30000 specjalistów, Żydów, i że dotrze 1000 nowych maszyn - a my czekamy końca! Beck z resortu powiedział mi dzisiaj, że Bronner wybiera to, co gęste, z mojej zupy. Pewnie ma rację, ale cóż mogę zrobić, cieszę się, że przynosi mi zupę i kiełbasę. W końcu kilka ziemniaków zawsze w zupie zostanie. Ci, którzy dzisiaj wyjechali, zabrali ze sobą wszystko, nie musieli tutaj niczego zostawiać i niczego im nie odebrano - mieli szczęście. 4000 praskich Żydów rzekomo przybyło do Warszawy, tam jest znacznie lepiej niż tu u nas. Czuję się stale zmęczony, nogi odmawiają posłuszeństwa, głównie więc siedzę i nie wiem, czy za tydzień będę mógł pracować w resorcie. Pod wieczór sprzedałem szlafrok i za zarobek 7,50 marek kupiłem spirytus i trochę cebuli. Na kolację zjadłem resortową zupę i 2 opiekane [kawałki] chleba z cebulą.

9 V Jest nas na kwarantannie 35 osób plus 3 osoby spoza kolektywu. Poprzednio $2 \mathrm{z}$ nas chodziło rano po kawę dla wszystkich i niosło ją do nas na trzecie piętro w bańce. Było to uciążliwe i dlatego teraz chodzimy rano po kawę sami, każdy dla kilku osób. Po zupę chodzi stale 2 ludzi, na przemian. Dotychczas było $1 / 2$ litra zupy dziennie, wczoraj był rwetes i od dzisiaj będzie się codziennie wydawało po 0,7 litra.

Ładna pogoda. Rano kęs chleba, musimy oszczędzać. Zastanawiam sie, co zrobię z butami, zdzierają się, a mam ostatnie 2 pary. Jedne są lekkie, całkiem 
jeszcze dobre, ale w drugich, które stale noszę, już jakiś czas temu naprawiałem obcasy. A i guma użyta w nich na podeszwy zaczyna szwankować. Poza tym kiepski humor. Lekarz opukiwał chorego Jirkę Fleischera, który leży już 5 dni z gorączką. Gramy znów w karty.

Coś charakterystycznego dla tutejszych warunków: pan Hirsch umarł 23 IV, a 6 dni później przyjechali tu po niego, aby odwieźć go do szpitala, do którego miał iść jakiś czas temu. Leżał 3-4 tygodnie w pokoju.

Po południu było weselej. Fasowaliśmy po $7 \mathrm{dkg}$ siekanego mięsa, $3 \mathrm{dkg}$ cukru, marmoladę i zapałki. Wcześniej pokłóciłem się z panią Hirschową w związku z jej synem. Mięso zaraz sobie przyrządziłem do chleba. Było ładnie i staliśmy na podwórku. Na kolację jadłem chleb z mięsem i mieszankę kawy z cukrem.

10 V Ostatnia niedziela na kwarantannie. Przypominam sobie ponownie niedziele w Pradze, gazety [czytane] na Nuslach ${ }^{58}$ w łóżku, rano kawę z deserem, psa, a przede wszystkim moją Ašę. Ona pewnie też wspomina. Jak często jeździ do mojej matki, a kiedy do Kojetic? I co robi jej matka? Dzisiaj jest u nas dzień matek. Jesteśmy zamknięci i nie wiemy, co się gdzie indziej dzieje, być może w Pradze obchodzą dzień matek. Krążą znów dobre wiadomości, podobno przemawiał B ${ }^{59}$.

Lang umiera. Pani Memková była w rewirze po zupę dla swojego męża, rozpoznali ją i mamy dziś zwiększoną względnie zaostrzoną kwarantannę. Mam nadzieję, że to przejściowe.

Na zewnątrz jest ładnie, ale nastrój podły. Niepokój pogłębiła wiadomość, że do biura dotarła masa nowych nakazów eksmisji, od nas dla G. Heller, Hamlišów i Hahnów. Pod wieczór umarł Lang. Pół dnia siedziałem na dworze na słońcu, przepisy znów na to pozwalają - nastrój się poprawił.

Fasowałem $15 \mathrm{dkg}$ twarogu, niestety nie mam już chleba. Na kolację zjadłem odgrzany resortowy barszcz czerwony. Kawałek twarogu dałem Hellerom, od których dostaję zupę i kawę. Na resztę twarogu przyjdzie kolej jutro, gdy znów będzie chleb.

$11 \mathrm{~V}$ Poranek bez chleba. Ugotowałem sobie zupę z resztek mąki $(1 \mathrm{~kg}$ [kosztuje] 500-600 marek). Snucie domysłów z panią Hahnovą. Ponowna dyskusja, czy ci, którzy mają nakaz wyjazdu, wyjadą po zniesieniu kwarantanny. Szkoda byłoby sióstr Robinson (57 i 59 lat), gotują mi, piorą i dbają o wszystko, to dla mnie terno ${ }^{60}$ przebywać $w$ ich towarzystwie, mają z nami mieszkać. Nikt nie wie, gdzie są ci, co wyjechali. Domniemywa się różne miejsca, ale nikt nic nie wie. W południe jadłem w kuchni kapuśniak i zaraz go zwróciłem. Nagle poczułem się niedobrze. Potem wyfasowałem chleb i wnet zjadłem go z twarogiem. Popołudnie spędziliśmy na słoneczku na podwórku. Pan kontroler poszedł ze mną do

${ }^{58}$ Nusle - dzielnica Pragi położona na prawym brzegu Wełtawy na południe od centrum (przyp. tłum.).

${ }^{59}$ Prawdopodobnie autor dziennika miał na myśli przemówienie prezydenta ČSR na emigracji Edvarda Beneša, transmitowane przez BBC (przyp. tłum.).

${ }^{60}$ Terno (wł.) - wygrany los na loterii (przyp. tłum.). 
drogerii. Sprzedałem kiełbasę za 8 marek pani Memkovéj (wczoraj za 10 marek pani Hellerovej, nie było chleba, a dzisiaj mam jeszcze twaróg), by mieć jakieś pieniądze. Właśnie była tu pani Nováková ze smutną wiadomością, że otrzymali nakaz wyprowadzenia się 13 [V]. Ciekaw jestem, kiedy wreszcie skończą się te transporty. Rodzina Fleischerów wysłała swego krewnego, ponoć jest z nim źle. Pani Hirschová musiała ustąpić 2 policjantom kanaliom za 10 marek buty pani Hellerovej - wczoraj wymieniona nie chciała ich oddać za 160 marek, to ilustracja tutejszych stosunków. 1 dkg margaryny kosztuje 7 marek, masło 11 marek, spirytus 5 marek - płacę prawie codziennie.

Wieczór wszystko naprawił. W zamian za slipy, skarpety i żyletki Mendelovič przyniósł mi pełny garnek bajecznie gęstej i dobrej zupy. Jeszcze teraz, po godz. 10 wieczorem, zabrałem się za nią, a rano o godz. 10 dokończyłem. Zaoszczędziłem przez to poranny chleb.

12 V Przed południem zupa, o której właśnie wspomniałem. Potem golenie. Paní Fleischerová użyczyła mi wody kolońskiej, którą tu zostawił jej bratanek. Pierwsza woda kolońska od z górą 6 miesięcy! Nieco pochmurno.

Wciąż dochodzą pieniądze z Pragi, ja jednak niczego nie dostaję, ale tak naprawdę nie potrzebuję pieniędzy. Na podstawie przesyłek można się zorientować, czy Żydzi jeszcze żyją w Pradze. A co z Jarką ${ }^{61}$ i Ančą? Co z mamusią? To dobrze, że opuściłem Pragę, czy powinienem tam zostać[?] Dzisiaj nie ważę nawet $65 \mathrm{~kg}$, co oznacza, że straciłem na wadze 20-25 kg. Odczuwam to głównie w nogach. Aša zdziwiłaby się, jak wyglądam, ja jednak zapomniałem zabrać z Pragi dużo rzeczy do zjedzenia, przede wszystkim zasmażki, kakao, kaszy manny, ryżu itd. To, co miałem, wkrótce zjadłem, a niektórzy mają zapasy jeszcze do dziś, oczywiście mężowie względnie żony. [Ludzie] stanu wolnego pospiesznie umierali i wymarli.

Gdzie się podziała moja energia[?] Byłem powiernikiem, naczelnym wodzem pokoju, naczelnym wodzem straży itd. Nastrój jest ponury. Kwarantanna trwa do soboty wieczorem. Nawet mi to nie przeszkadza. Dostaję zupę i kiełbasę oraz 2,20 marki wypłaty dziennie. Teraz to się opłaca. Gorzej jest z wezwaniami. Nawet ludzie z resortu muszą iść, odwołania są odrzucane, gdyż kontyngent jest nazbyt duży, a nas mało. Wyznaczani się już także Polacy, których wcześniej ochraniał Aelteste.

Wieczorem przyszła dobra resortowa zupa, właściwie kapusta z ziemniakiem Ia [?]. Byłem na zewnątrz i zarobiłem 40 marek, wymieniłem też czarną pastę do butów na kiełbasę względnie 13 marek. Wieczorem padał deszcz. Potem znów dobra kolacja, do kapusty jeszcze chleb z kiełbasą.

13 V 1942 Dzisiaj Aša ma urodziny. Wiem, że nie będą radosne. W myślach życzę jej wszystkiego najlepszego, zasługuje na to. Może się jeszcze w tym roku zobaczymy.

${ }^{61}$ Jaroslav Hahn był młodszym bratem Viktora. Wraz z żoną Anną (Ančą) oraz córką Haną zostali deportowani 23 VII 1942 r. z Pragi do Terezina, a stamtąd na początku września 1942 r. na wschód - prawdopodobnie do Estonii - gdzie zostali zamordowani. 
W nocy miejscowa policja wkroczyła do kolektywu i zabrała wielu znajomych, którzy dopiero dziś mieli stawić się na miejscu zbiórki. Podobno jeszcze dziś odjeżdżają. Złowili 300 ludzi do kontyngentu. W niektórych pokojach była to ponoć straszna noc.

Rano była u mnie Novákova, która czeka na rozpatrzenie podania, w przeciwnym razie jeszcze dziś musiałaby wyjechać. Może im to odłożą. Bardzo niechętnie by poszli!

W nocy policjanci poszukiwali także ludzi od nas. Gdyby nie nasza „złota” kwarantanna, byłoby nas dzisiaj o wiele mniej. Z tego wynika, że nigdy nie wiadomo, co jest dla kogo dobre. Niemniej pani Robinsonová uszyła mi 3 worki, na wszelki wypadek.

To dziwny kraj. Tylu much i tylu wron łącznie nigdy nie widziałem.

Nastroje są rozchwiane. Wszyscy są nerwowi i każdy trochę wariuje. To z głodu. Każdy wspomina końskie mięso i kiełbasę, jednego i drugiego było tu dość, gdy przyjechaliśmy, a wielu nie chciało tego jeść. Innego mięsa tu nigdy nie było i nie ma, tylko końskie, ale teraz prawie się go nie widuje. $1 \mathrm{dkg}$ kosztuje około 1-1,50 [marki] i jest trudno dostępne. Inny rarytas: jajka nie widziałem tutaj przez całe 6 miesięcy, gdy tu jestem, jajka po prostu tu nie docierają. Mleko tu było na samym początku, teraz także go nie uświadczysz. Kakao kosztuje 8 marek za $1 \mathrm{dkg}$.

Dobrze to tutaj nie jest.

${ }^{a} 0$ urodzinach Ašiny będę pamiętał. Po południu przyszła pani Nováková, że powinni wieczorem wyjechać, ich prośba nie została uwzględniona. W tym samym czasie dowiedziałem się, że poszukują 200 mężczyzn do [budowy] autostrady w Poznaniu. Nováková poprosiła mnie, abym im jeszcze coś przed południem sprzedał, co też zrobiłem, i byłem u nich dwa razy. Równocześnie zgłosiłem się ochotniczo do Poznania i jutro rano idę na zbiórkę. Dostawałbym tam 3 [porcje] zupy i $60 \mathrm{dkg}$ chleba dziennie, ciekaw jestem, jak to jutro będzie.

Wieczorem nam jednak oznajmiono, że kwarantanna jest zniesiona.

Za 5 dkg łoju zapłaciłem 50 marek, za $50 \mathrm{dkg}$ margaryny 45 marek.

Każdy boi się tego, co przyniesie noc, czy nie przyjdzie policja po kogoś z nas.

Kupiłem sobie jeszcze wieczorem $3 \mathrm{dkg}$ cukru za 15 marek i zmieszałem to ze zmiotkami kawy, aby zaspokoić głód względnie apetyt, bo faktycznie dobrze wieczerzałem. Były resortowa zupa i chleb z łojem.

Mieszanka kawy z cukrem smakuje bardzo dobrze. Potem mi jeszcze Mendel przyniósł o godz. 11 trochę zupy. Nikomu nie chciało się iść spać, panowała wielka nerwowość, większość pakowało swe rzeczy i przygotowywało się do odjazdu. ${ }^{a}$

$14 \mathrm{~V} 0$ godz. 5 rano policja rzeczywiście przyszła po Kummermannów. 0 godz. 8 staję do poboru, uznany za zdolnego, o godz. 5 muszę być na zbiórce. Polscy lekarze badali nas dokładnie, byliśmy całkiem nadzy. Stamtąd poszedłem do resortu po zupę i pieniądze za kwarantannę, wypłacili mi aż 56 marek, zaraz za nie kupiłem jedzenie na drogę. Potem byłem u Sašy, pani dała mi kawałek chleba z marmoladą, aż wreszcie byłem u Guttmannów, gdzie sprzedałem 
za 30 marek płaszcz. Starsza pani dała mi cukierki i kawałek margaryny. Gdy wróciłem, zjadłem zupę, a pani Fleischerová potem mi wszystko zapakowała. Ledwie to zrobiła, do pokoju wkroczyła policja i zabrała względnie miała rozkaz wkrótce doprowadzić wszystkich, nie czyniąc wyjątku dla Fleischerovej, Nettlovej ani mnie. Polski bałagan! Zostałem zwolniony, ale mimo to zmuszono mnie do wyjścia. Dobrze, że zgłosiłem się do Poznania. Walizki odniosłem najpierw na dwa razy do Sašy, a potem na miejsce. Lekko nie było, wciąż musiałem odpoczywać. Cieszę się, że jestem w pomieszczeniu, tj. w garażu, gdzie będziemy dzisiaj spać. Przed opuszczeniem kolektywu dostałem adresy, na które mam pisać, i pół chleba (przez pomyłkę więcej). Po potwierdzenie, że jadę do Poznania, musiałem gonić osobiście, bojąc się, jak to się skończy. Teraz będzie wieczorna zupa, potem znów pół chleba, a rano wyruszamy. Zobaczymy.

$15 \mathrm{~V}$ Dali nam więc o godz. 9 wieczorem kawę, a po godz. 10 doskonałą zupę. Było nas mnóstwo, wielu nie spało, ja miałem jednak dobre miejsce i leżałem, więc było dobrze. Rano znów zupa, a potem kawa.

Następnie $1 / 2$ chleba i szło się na Balutenring ${ }^{62}$. Bagaże, których mam wiele, pomógł mi nieść pan Kasza. Stało się tam, a następnie do elektryki ${ }^{63}$. Tu wszystko się zaczęło: szliśmy względnie jechaliśmy najpierw do łaźni na kąpiel i odwszenie wszystkich rzeczy parą. Walizkę uratowałem, chyba jako jedyny. Wszystko, co skórzane, zniszczy się od tego gorąca. Bito tam grubym kijem wszystkich. Potem znów elektryką do $\mathrm{SS}^{64}$ na spis, następnie stanie na zewnątrz w największym deszczu i w końcu szło się do obozu. Sam niosłem walizkę i to była moja krzyżowa, straszna droga. Ledwo doszedłem. Obiecali mi bicie. W obozie lali nawet za to, że niektórzy mieli czapki na głowie. Potem było trochę kawy, dali nam ją Żydzi z Pabianic, którzy są tu z nami.

$16 \mathrm{~V}$ Jest nas wielu i dlatego noc była kiepska. Nie spałem. Rano wydali nam 1 chleb na 8 osób, a potem dobrą kawę zbożową. Wczoraj i dzisiaj wciąż pada deszcz. Ci z Pabianic dzisiaj wyjeżdżają, dokąd - nie wiedzą.

Wczoraj o godz. 8 była przez te niezdjęte czapki półgodzinna musztra. Padnij, powstań, ale nam to chyba nie zaszkodziło, z wyjątkiem zabrudzenia. Jest tu jednak okropnie, obyśmy stąd odeszli. Wiele nam tu nie obiecują do jedzenia w związku z Poznaniem. Na odwrót, będzie go ponoć mniej niż w getcie!! Będzie jednak można pisać, a to jest najważniejsze. Drogo tam pewnie także nie będzie i będę sprzedawał swoje rzeczy. W Pabianicach chleb kosztował 5 marek, a chłopcy szukali koszul, skarpet itd. Przed południem znów około 30 minut musztry, a następ-

${ }^{62}$ Przy Bałuckim Rynku obok biur Przełożonego Starszeństwa Żydów i niemieckiego Zarządu Getta mieściły się punkt zborny dla robotników wysyłanych do pracy poza gettem oraz punkt dezynfekcji. Od południowej - punkt zborny i przystanek tramwajowy

${ }^{63}$ Tzn. tramwajem (przyp. tłum.).

${ }^{64}$ Autor wraz z grupą innych robotników przymusowych został przewieziony tramwajem prawdopodobnie do jednego z obozów przejściowych na terenie Litzmannstadt, zorganizowanych w dzielnicy Polesie w bezpośrednim sąsiedztwie dworca kolejowego Litzmannstadt-Hauptbahnhof (Łódź Kaliska). 
nie przegląd, podczas którego nas podzielili. Dobra zupa, choć trochę mało, potem znów przegląd, na którym nas policzyli, 120 ludzi, wśród nich ja, jedzie rano nie wiadomo dokąd, ale prawdopodobnie do Poznania. Ballenberg i Fleischer z nami nie jadą. Potem znów staliśmy w deszczu, nie wiem dlaczego, rozmaite obrazki żebyśmy już pojechali! Wieczorem kawa, nie mam już chleba. Pada deszcz i jest zimno. W nocy będziemy mieli więcej miejsca, rano wyjechali pabianiczanie.

Przeziębiłem się i mam lekką biegunkę. 0 godz. 8 znów musztra. To był cyrk, porządni dowódcy. W nocy Polacy strasznie krzyczeli, ponownie zginął chleb (codziennie kilka [bochenków]), leżałem i trochę spałem.

$17 \mathrm{~V}$ Niedziela. Godz. 7 rano, wspominam, że w domu wszyscy śpią. $25 \mathrm{dkg}$ chleba, kawy nie chcę, biorę calcium ${ }^{65}$. Znów pada deszcz i czekamy względnie cieszymy się, że już [wkrótce] ktoś po nas przyjdzie. Szkoda każdej chwili spędzonej w tym budynku na cementowej posadzce. Polacy to okropni ludzie, to są zwierzęta, nie wiem, jak dalej będzie układać się między nimi a nami!

25 dkg chleba na drogę to mało, ale co można zrobić? Rano wziąłem tylko mały kawałek i posypałem kakao, może biegunka przejdzie. Jestem całkowicie spakowany i czekam. Jest godz. 9 rano.

Chwilę później zagoniono nas z rzeczami na podwórko i maszerowaliśmy 10-15 minut na dworzec. Wyjechaliśmy punktualnie o godz. 11. Wszędzie długie postoje, w Kaliszu i na innych stacjach. Teraz jest w pół do siódmej i stoimy już półtorej godziny w Ostrowie. Od rana nic nie piłem, zjadłem tylko $25 \mathrm{dkg}$ chleba, niczego innego nie miałem i dlatego jestem strasznie głodny. Inni także. Cała trasa przez równinę. Wszędzie się dużo buduje i jest duży ruch. Wszędzie dużo stojącej wody, ale teraz już świeci słońce. Bagaże znów ciążą. Dałem komuś do niesienia śpiwór, może mi go zwróci. Jest w drugim wagonie.

Niektóre pociągi mają wagony: Für Polen zugelassen ${ }^{66}$.

0 godz. 10 dojechaliśmy. 0 półtoragodzinnej drodze nie chcę nadmieniać, raz jeszcze miałem szczęście, policjant niósł mi walizkę, kiedy już nie mogłem. Czekała kolacja lub przynajmniej kawa, ponieważ nie było obiadu, natomiast znaleźliśmy się znów po półtorej godziny w łaźniach na nowym odwszaniu. Trwało to do godz. 8 rano. Stamtąd szliśmy przez to ładne miasto około 3 godzin do obozu, bez snu i bez jedzenia. W południe była tutaj dobra zupa, cały litr. Po południu nasza grupa poszła od razu dość ciężko pracować, wyrównywać podkłady ${ }^{67}$. Jest tu piękna okolica, a obozowisko mamy na ładnym i zdrowym leśnym obszarze. Materace, talerze, kubeczki i łyżki dostaliśmy - miła niespodzianka, w Łodzi spaliśmy na deskach.

Pomieszczenie jest wielkie.

${ }^{65}$ Wapno, trudno dostępne na czarnym rynku w getcie, pochodziło prawdopodobnie z zapasów autora.

${ }^{66}$ Für Polen zugelassen (niem.) - dozwolony dla Polaków.

${ }^{67}$ Hahn był zatrudniony przy pracach budowlanych na kolei - w miejscowości Kobylepole obok obozu pracy znajdowała się rozległa bocznica kolejowa. 
Pisałem 2 karty [pocztowe] do Ašy i kartę [pocztową] do matki. Druga miła niespodzianka. Pakiety są dozwolone.

18 V Uzupełnienie: jeszcze po południu wyrównywaliśmy legary (podkłady).

19 V Ciężki dzień: cały dzień nosiliśmy podkłady, aż do godziny 6. List do Ašy.

20 V Cały dzień nosiliśmy cement. Znów kartka do Ašy.

$21 \mathrm{~V}$ Cement $\mathrm{i}$ jazda samochodem.

Karta [pocztowa] do Emila, Lessów, Hanzima i Poláčka. Dobrze, poza tym cementowe rury i rany. 2 [porcje] zupy wieczorem.

22 V Całkiem spokojny dzień. Karta [pocztowa] do Ašy. Rozładowywanie wagonów.

$23 \mathrm{~V}$ Wyładowywanie $\mathrm{z}$ wagonów drewna na baraki. Wożenie kotłów do kuchni. Ponadto list do Ašy.

24 V Pierwsza niedziela, wypoczynek, mycie i pranie jednej koszuli. Piękny dzień, obolały kciuk prawej ręki, a muszę pisać.

Rano kawa, $25 \mathrm{dkg}$ chleba i marmolada, do tego 2 razy w tygodniu $2 \frac{1}{2} 2 \mathrm{dkg}$ margaryny. W południe 1 litr gęstej zupy, a wieczorem znów $1 / 2$ litra zupy, ale niezbyt gęstej z ziemniakami. Jedzenie jest jednak dobre, dobrze przyprawione, kawa słodzona sacharyną. Tempo pracy jest za to duże.

25 V Nawet nie wiedziałem, że są święta, poniedziałek po Zesłaniu Ducha Świętego, dopiero wieczorem mi to powiedzieli. Ładny dzień, lżejsza praca. Zamieniłem koszulę na 2 porcje chleba i kolację. Kupiłem ją w getcie za 15 marek.

26 V Znów ładny dzień i spokojniejsza praca, nie licząc 15 minut noszenia cementu do wagonu. Na kolację miałem 3 [porcje] zupy, świetna grochówka w południe, sprzedałem palto, co mam robić, jestem stale głody, a palta tu nie potrzebuję. Mam za nie codziennie chleb i inne rzeczy do jedzenia, stąd bym go już zresztą nie wywiózł. Aša ma już pewnie ode mnie wiadomości - gdzie była w święta? Czekam na pocztę.

Na polecenie getta dostałem karty [pocztowe]. 3 [porcje] zupy.

27 V Obijanie się przy torach, podkopywanie, 40 marek i cukier za palto. Wieczorem porządnie przemokłem przy noszeniu ziemniaków. Zjadłem 5 [porcji] zupy, a w południe i rano po $25 \mathrm{dkg}$ chleba.

28 V Podkopywanie przez cały dzień w upale. Dzień mija wolno. List od Lesse. Pierwszy list.

Z języka czeskiego przełożył Sławomir M. Nowinowski

BIBLIOGRAFIA

Źródła archiwalne

Archiwum Państwowe w Łodzi (AP Łódź)

Akta Przełożonego Starszeństwa Żydów (PSŻ), 1290

ITS Digital Archive, Arolsen Archives (ITS AA)

1490553, Victor Hahn

United States Holocaust Memorial Museum (USHMM)

RG-19.027, List of Czechoslovakian displaced persons in Ebensee, 18 V 1945 


\section{Źródła publikowane}

Encyklopedia getta. Niedokończony projekt archiwistów z getta łódzkiego, wyd. Krystyna Radziszewska i in., Łódź: Wydawnictwo UŁ, 2014.

Ghetto Litzmannstadt 1941-1944. Dokumenty a výpovědi o životě czeských židů v lodžském ghettu, oprac. Richard Seeman, Praha: Ústav mezinárodních vztahů ve spolupráci s Terezínským památníkem, 2000.

Hauser Irene, Dziennik z getta łódzkiego / Das Tagebuch aus dem Lodzer Getto, red. Ewa Wiatr, Krystyna Radziszewska, Łódź: Wydawnictwo UŁ, 2019.

Heilig Bernard, Pierwsze siedem miesięcy w getcie Litzmannstadt. Przelotne wrażenia i obrazy [w:] Oblicza getta. Antologia twórczości z getta łódzkiego, red. Krytyna Radziszewska, Ewa Wiatr, Łódź: Wydawnictwo UŁ, 2017.

Kronika getta łódzkiego / Litzmannstadt Getto 1941-1944, t. 1-5, red. Julian Baranowski i in., Łódź: Wydawnictwo UŁ i Archiwum Państwowe w Łodzi, 2009.

Oblicza getta. Antologia twórczości z getta łódzkiego, red. Krytyna Radziszewska, Ewa Wiatr, Łódź: Wydawnictwo UŁ, 2017.

„Przemierzając szybkim krokiem getto...” Reportaże i eseje z getta łódzkiego, tłum. Krystyna Radziszewska, Łódź: Oficyna Bibliofilów i Archiwum Państwowe w Łodzi, 2002.

Rok za drutem kolczastym. Na marginesie obwieszczeń Pana Prezesa Ch. Rumkowskiego. Obwieszczenia Przełożonego Starszeństwa Żydów z getta łódzkiego (1940-1944), oprac. Adam Sitarek, Ewa Wiatr, Warszawa: Ż̇H, 2019.

Rosenfeld Oskar, Wozu noch Welt? Aufzeichnungen aus dem Getto Lodz, oprac. Hanno Loewy, Frankfurt am Main: Neue Kritik, 2014.

Sierakowiak Dawid, Dziennik, oprac. Ewa Wiatr, Adam Sitarek, Warszawa: ŻIH, 2016.

\section{Opracowania}

Alberti Michael, Die Verfolgung und Vernichtung der Juden im Reichsgau Wartheland 1939-1945, Wiesbaden: Harrassovitz Verlag, 2006.

Leociak Jacek, Tekst wobec Zagłady. (O relacjach z getta warszawskiego), Wrocław: Fundacja na Rzecz Nauki Polskiej, 1997.

Löw Andrea, Getto łódzkie / Litzmannstadt Getto. Warunki życia i sposoby przetrwania, tłum. Małgorzata Półrola, Łukasz Marek Plęs, Łódź: Wydawnictwo UŁ, 2012.

Sitarek Adam, „Otoczone drutem państwo”. Struktura i funkcjonowanie administracji żydowskiej getta łódzkiego, Łódź: IPN, 2015.

Sitarek Adam, „W obliczu trudnej konieczności”. Administracja żydowska getta łódzkiego wobec wsiedleń Żydów z Rzeszy i Protektoratu (październik-listopad 1941 r.), „Zagłada Żydów. Studia i Materiały" 2012, nr 8.

Ziółkowska Anna, Obozy pracy przymusowej dla Żydów w Wielkopolsce $w$ latach okupacji hitlerowskiej (1941-1943), Poznań: Wydawnictwo Poznańskie, 2005. 